\title{
Bottom of an iceberg: undiagnosed aortic aneurysm masquerading as vocal cord palsy
}

\author{
Vishal U S Rao, ${ }^{1}$ Sataksi Chatterjee, ${ }^{2}$ Shivakumar S Swamy ${ }^{3}$
}

${ }^{1}$ Department of Surgical Oncology (Head and Neck Surgery), HealthCare Global Enterprises Ltd, Bangalore, Karnataka, India

${ }^{2}$ Department of Surgical Oncology, HealthCare Global Enterprises Ltd, Bangalore, Karnataka, India

${ }^{3}$ Department of Radiology, HealthCare Global Enterprises Ltd, Bangalore, Karnataka, India

\section{Correspondence to}

Dr Vishal U S Rao,

drvishalrao@yahoo.com

Accepted 20 January 2017

\section{DESCRIPTION}

A previously healthy woman aged 60 years was referred to a tertiary referral cancer centre with change of voice for 1 week suspecting neoplastic aetiology on account of her tobacco chewing habit of more than 20 years. No history of voice abuse, fever or cough was there preceding the onset of the change of voice. She did not have any previous history of hospitalisation or diagnosed comorbidities. On clinical examination, her pulse rate was $82 \mathrm{bpm}$; blood pressure was 130/90 $\mathrm{mm} \mathrm{Hg}$ and respiratory rate was $12 / \mathrm{min}$.

Video laryngoscopy examination revealed left vocal cord palsy with no obvious lesion. A wholebody F18 FDG PET-CT scan revealed the presence of $6.6 \times 4.8 \times 6.7 \mathrm{~cm}$ lobulated sacullar aneurysm arising from the aortic arch between the origins of the left common carotid and subclavian arteries

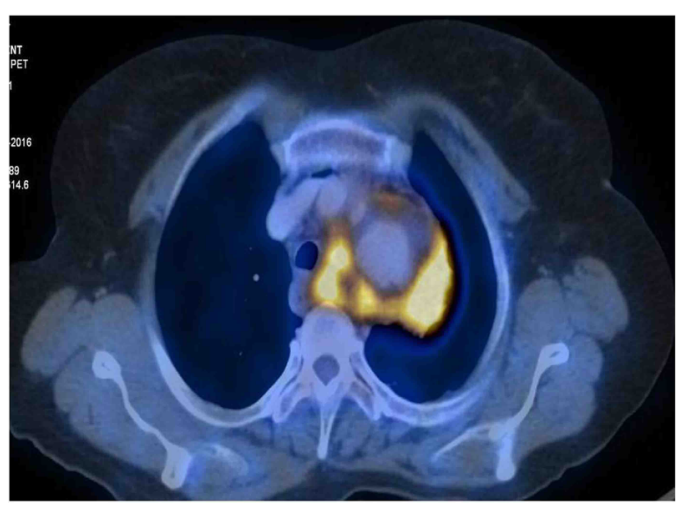

Figure 1 PET-CT image (axial cut) of the chest showing large lobulated sacullar aneurysm arising from the aortic arch between the origins of the left common carotid and subclavian arteries, measuring $\sim 6.6 \times 4.8 \mathrm{~cm}$ in transaxial dimensions and $6.7 \mathrm{~cm}$ craniocaudally. The anatomical location of the aneurysm corresponds to that of the left recurrent laryngeal nerve.
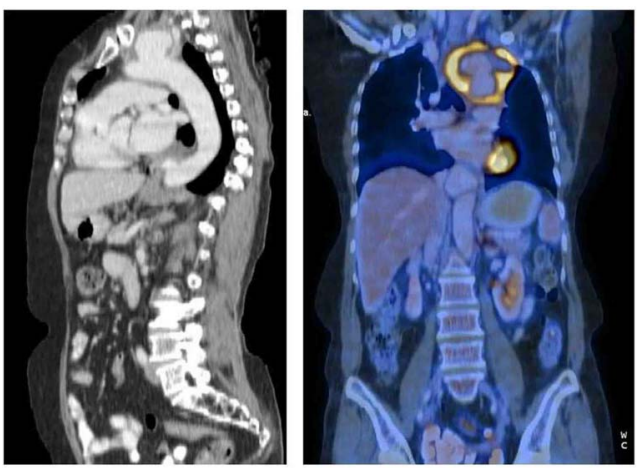

Figure 2 Contrast-enhanced CT image (axial cut) of the chest showing the aortic aneurysm causing compression of the proximal carotid artery.

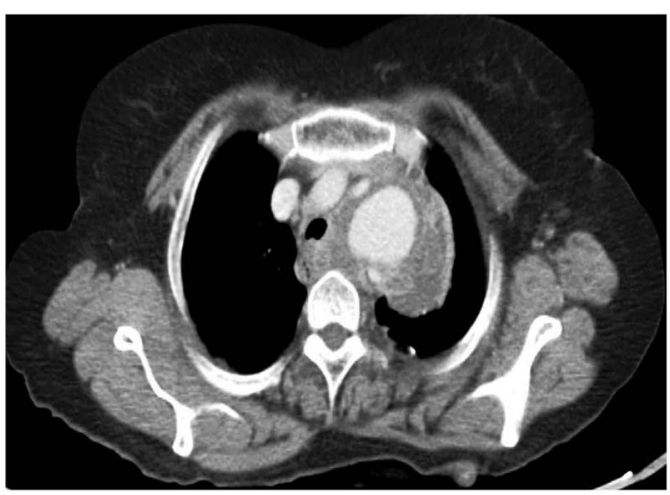

Figure $3 \mathrm{CT}$ and PET-CT images (saggital and coronal cut) of the chest showing the presence of an eccentric thrombus of maximum thickness of $2.6 \mathrm{~cm}$ around the aortic aneurysm causing compression of the thoracic trachea and proximal oesophagus.

(figures 1 and 2). The likely mycotic aneurysm caused significant surrounding metabolically active inflammatory changes (figure 3). The cause of left vocal cord palsy was due to compression of the left recurrent laryngeal nerve.

More often than not such 'common presentations' of uncommon yet sinister causes are missed subjecting the patients to undergo myriads of tests, thus delaying definitive management. ${ }^{1-3}$

\section{Learning points}

- Considering the tobacco consumption history, advanced age and change in voice, the patient was referred to an oncology centre. However, this case of vocal cord palsy highlights the point that the oncologists should have a high index of suspicion regarding other possible benign aetiologies while evaluating such cases.

- Uncommon cases like aortic aneurysm can masquerade themselves to a commoner clinical presentation like vocal cord palsy and might get misdiagnosed delaying the treatment. ${ }^{12}$

- The imaging modality of choice in such cases of vocal cord palsy without any evident lesion in endoscopy should extend from the skull base to thorax. ${ }^{3}$ Without prior evaluation of the thorax, subjecting these patients to more invasive diagnostic modalities like evaluation under anaesthesia can result in catastrophic anaesthetic complications.

Twitter Follow Shivakumar Swamy @dr.shivaswam

Contributors The authors take the responsibility of the originality of the article and state that they both have contributed to the article. VUSR is the guarantor, primary consultant of the patient 


\section{Images in...}

and played the key role in establishing the clinical diagnosis. SC is part of the primary consultant's team, helped in establishing the clinical diagnosis and wrote up the article. SSS is the consultant radiologist to evaluate the scan and helped establish the radiological diagnosis.

Competing interests None declared.

Patient consent Obtained.

Provenance and peer review Not commissioned; externally peer reviewed.

\section{REFERENCES}

1 Rizvi MM, Singh RB, Jain A, et al. Asymptomatic aortic aneurysm causing right vocal cord palsy and hoarseness: a rare presentation. Anesth Essays Res 2014;8:397-400.

2 Laccourreye $\mathrm{O}$, Malinvaud $\mathrm{D}$, Ménard $\mathrm{M}$, et al. [Unilateral laryngeal nerve paralysis in the adult: epidemiology, symptoms, physiopathology and treatment]. Press Méd 2014;43(Pt 1):348-52.

3 Glazer HS, Aronberg DJ, Lee JK, et al. Extralaryngeal causes of vocal cord paralysis: CT evaluation. AJR Am J Roentgenol 1983;141:527-31.

Copyright 2017 BMJ Publishing Group. All rights reserved. For permission to reuse any of this content visit http://group.bmj.com/group/rights-licensing/permissions.

BMJ Case Report Fellows may re-use this article for personal use and teaching without any further permission.

Become a Fellow of BMJ Case Reports today and you can:

- Submit as many cases as you like

- Enjoy fast sympathetic peer review and rapid publication of accepted articles

- Access all the published articles

- Re-use any of the published material for personal use and teaching without further permission

For information on Institutional Fellowships contact consortiasales@bmjgroup.com

Visit casereports.bmj.com for more articles like this and to become a Fellow 